\title{
Strategies for creating equitable urban greenspace in global cities
}

\author{
Review by Chhaya Kolavalli * \\ University of Kentucky
}

\author{
Review of Just Green Enough: Urban Development and Environmental \\ Gentrification, edited by Winifred Curran and Trina Hamilton. \\ (2018). Published by Routledge. Available as hardcover, \\ paperback and ebook; 248 pages. Publisher's website: \\ https://www.routledge.com/Just-Green-Enough-Urban- \\ Development-and-Environmental-Gentrification/Curran- \\ Hamilton/p/book/9781138713826
}

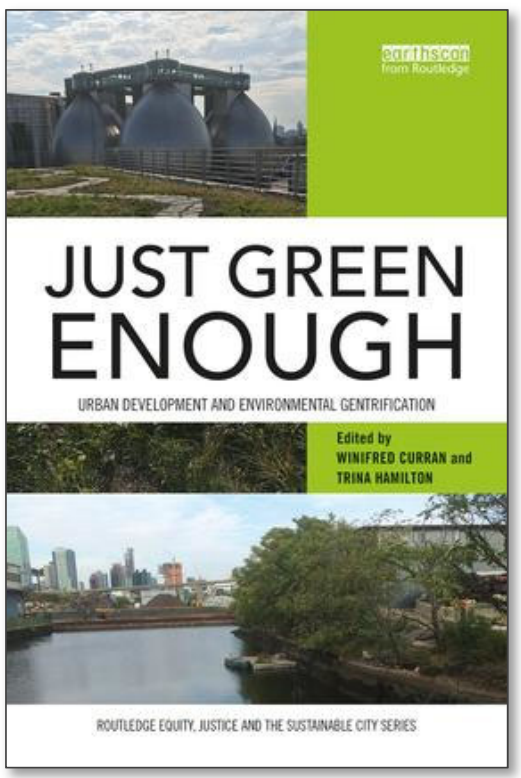

Submitted February 16, 2018 / Published online March 29, 2018

Citation: Kolavalli, C. (2018). Strategies for creating equitable urban greenspace in global cities [Book review]. Journal of Agriculture, Food Systems, and Community Development, 8(1), 193-195. https://doi.org/10.5304/jafscd.2018.081.014

Copyright (C) 2018 by the Author. Published by the Lyson Center for Civic Agriculture and Food Systems. Open access under CC BY license.

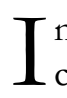
ncreasing attention, globally, is being paid to the creation of "green" urban space as a strategy for mitigating and adapting to climate change-as

Chhaya Kolavalli is a $\mathrm{PhD}$ candidate in anthropology at the University of Kentucky. Her research interests include racialized inequality, U.S. social policy, gentrification, and green urban development. Her dissertation research examined "green" urban development initiatives in highly segregated Kansas City, Missouri. Her work explored the histories of urban space and inequality that are elided in these development initiatives by highlighting the narratives of "food desert" residents, whose neighborhoods have been targeted for redevelopment. Ms. Kolavalli can be contacted at crkolavalli@gmail.com. cities account for more than 70 percent of greenhouse gas emissions. While cities are major contributors to climate change, they can also be primary drivers in the direction of positive change, since they hold authority over key climate-related policies, such as those concerning land use zoning and industrial emissions. In that light, as many cities take up the task of developing green urban infrastructure-including promoting and supporting urban food systems-it is critical to understand how to enact these changes equitably, so that all urban residents benefit from sustainability initiatives. Because cities will be most affected by food supply and distribution problems caused by climate 
change, their support of robust, diverse, and sustainable urban food production can be of major significance in an era of climate uncertainty.

Just Green Enough: Urban Development and Environmental Gentrification provides an important intervention by offering actors involved in mitigating urban climate change a guidebook of strategies for equitable green development. It speaks broadly about the topic of urban greening, primarily focusing on issues caused by environmental hazards in the built environment. Several chapters touch specifically on urban food production and distribution. While many of the tactics offered for equitable development are geared toward those focused on environmental remediation, urban planners, activists, and community members working specifically in urban food systems will find the strategies easily applicable to their own work.

The papers brought together in Just Green Enough all center around editors Winifred Curran and Trina Hamilton's concept of "just green enough (JGE)" - a community vision and organizing strategy born out of their work in Greenpoint, Brooklyn, that's meant to uncouple environmental cleanup from environmental gentrification (p. 3). Environmental gentrification, the central concern of the case studies presented, refers to the process by which "environmental concerns are co-opted in order to facilitate high-end development, resulting in the displacement of lower-income residents" (p. 2). A thread carried throughout the book is a critique of the "global urban growth machine," which profits from urban environmental problems and their solutions (Gould \& Lewis, 2017). The authors work to counter the efforts of this "machine" by focusing on supporting social justice and environmental goals as defined by the local communities themselves that experience environmental inequities (p. 3).

Chapters in the book all center on JGE, exploring its manifestation in different global contexts. Part one of the book, Just green enough in transition, brings together several chapters that effectively workshop the concept—drawing on case-study material to examine how JGE works in practice, and how it may or may not be an effective long-term strategy for equitable green development. In part two, Green displacements and community identity, three chapters discuss how green development projects have led to the loss of community identity in different contexts. Part three, State-led environmental gentrification, focuses on the role of the state, in particular, in shaping the outcomes of green urban development. The final section, Mobilizing and planning for just, green futures, presents case studies that explore how various communities have mobilized and fought environmental gentrification, and offers strategies useful for community organizers and activists.

Two chapters in particular offer useful insight for those working in food systems change and community development: Chapter 6, "Alternative food and gentrification: Farmers' markets, community gardens and the transformation of urban neighborhoods," and Chapter 14, "Informal urban green space as anti-gentrification strategy?" Chapter 6 lays out an argument for how the alternative agrifood movement has been hijacked to serve the urban elite and to reproduce white privilege, arguing for example that in San Diego, urban food projects are purposefully capitalized on by urban renewal agendas and real estate agents to displace low-income residents and people of color. The authors offer several strategies for reclaiming alternative agrifood projects, including advocating for affordable housing and equitable zoning policies in areas where farmers markets and community gardens are created (p. 103).

Chapter 14 draws on ethnographic analysis in Australia and Japan, documenting how informal green spaces in these contexts are more resistant to environmental gentrification than formalized statedeveloped green spaces. The authors present examples of urban food production in Sapporo, Japan, where neighborhood residents capitalize on vacant, low-profile, urban space to grow food in storm water runoff sites, roadside plots, and power line corridors-pointing toward the possibility that urban planners should allow neighborhood residents themselves to identify and manage green space as they see fit.

The recommendations offered in part 4 will be particularly useful for community leaders, activists, and urban planners working to craft equitable urban food systems in the era of climate change. Authors here highlight the strong value of compre- 
hensive neighborhood planning projects rather than atomized, isolated efforts. They also point out the vital role that a strong place-based identity can play in mobilization and community strength-one that draws on and brings to light histories of racism in a neighborhood. Finally, they describe the importance of intentionality, noting that environmentally just neighborhoods do not simply happen; environmental and food justice must be an integral part of any project's development from day one. Just Green Enough makes clear that environmental and food justice advocates can create equitable, sustainable projects in urban spaces, as long as we take care to "hardwire in" social and racial equity from the start (p. 228).

\section{Reference}

Gould, K. A., \& Lewis, T. L. (2017). Green gentrification: Urban sustainability and the struggle for environmental justice. New York and London: Routledge. 